\title{
Ortaokullarda Demokrasi Eğitimi İçeriğine İlişkin Öğretmen
}

\section{Görüşlerinin Karşılaştırılması*}

\author{
${ }^{1}$ Recep DÜNDAR, ${ }^{2}$ Özcan EKİCİ \\ ${ }^{1}$ Doç.Dr., Inönü Üniversitesi, recep.dundan@,hotmail.com \\ ${ }^{2}$ Dr, Dicle Üniversitesi, ozcan44@,botmail.com
}

DOI: http://dx.doi.org/ 10.14582/DUZGEF.1914

\begin{abstract}
ÖZ
Bu araştırmanın amacı, Avusturya ve Türkiye'deki ortaokullarda demokrasi eğitimi içeriğinin öğretmen görüşleriyle yeterliliğini belirleyip, karşılaştırabilmektir. Çalışma nitel araştırma yöntemlerinden durum çalışması temelli yapilmıştır. Araştırmanın çalışma grubunu, Diyarbakır il merkezinde yer alan ortaokullarda görev yapan Sosyal Bilgiler öğretmenleri ile Viyana şehir merkezinde yer alan ortaokullarda görev yapan, toplam 100 Tarih ve Sosyal Bilgiler ögretmenleri olușturmaktadır. Araştırmada, çalışma grubunun seçilmesinde amaçlı örnekleme yöntemlerinden ölçüt örnekleme kullanılmıştır. Çalışma grubunu oluşturan Türkiye ve Avusturya'daki tarih ve sosyal bilgiler öğretmenlerinin demokrasi eğitimine ilișkin, görüșlerini belirlemek amacıyla 5 sorudan oluşan yarı yapılandırılmıș görüșme formu kullanılmıștır. Araştırma sonucunda elde edilen verilere göre Türkiye ve Avusturya'daki öğretmenlerinin demokrasi kavramına ilişsin algıları birbirinden farklı olsa da genelindeki algılarının "ifade özgürlüğü" ekseninde birleştiği tespit edilmiştir. Ayrıca Türkiye'de ortaokullarda yer alan öğretim programlarında demokrasi eğitimini temele alan kazanımların öğretmenler tarafindan yetersiz bulunduğu, Avusturya'da ortaokullarda hazırlanıp uygulanan öğretim programlarında demokrasi eğitimini temele alan kazanımların öğretmenler tarafindan yeterli bulunduğu belirlenmiştir. Avusturya'da ortaokullarda demokrasi eğitimine yönelik kazanımların, değerlerin daha çok sosyal ögrenme kuramına dayalı olarak öğrenciye aktarılmaktadır. Türkiye'de demokrasi eğitimine yönelik olarak öğrenciye aktarılması gereken nitelikleri aktarmada öğretmenlerin yeterlilik eksiklikleri olmasına rağmen Avusturya'da böyle bir durumun çok fazla olmadığı tespit edilmiştir. Türkiye'de demokrasi eğitiminin daha çok değerlere, Avusturya'da ise bilgiye yönelik olduğu belirlenmiştir.
\end{abstract}

Anahtar Kelimeler: Demokrasi, Demokrasi Eğitimi, Sosyal Bilgiler Eğitimi

\section{Comparison Of Teachers' Views On The Content Of Democracy Education İn Secondary Schools}

\begin{abstract}
The aim of this study is to compare the qualification of the content of democracy education in the secondary schools in Austria and in rapidly democratizing Turkey by determining the teachers' notions. The survey was carried out on the basis of case study of qualitative research designs. This study group of the research encompasses the social science teachers located in the centre of the Diyarbakır province with a total of 100 teachers of history and social science teachers serving in the secondary schools located in the centre of Vienna. In the research, criterion sampling from purposive sampling methods was used for selection of the study group. Semi-structured interview including five openended questions was applied for assessing the notions on democracy education of the history and social science teachers forming the study group in Turkey and in Austria. Although the perceptions of the democracy concept of teachers in Turkey and in Austria are different, it is identified that general perceptions are united around "freedom of speech". It is determined that acquisitions based on democracy education in the curriculums which are in the secondary schools in Turkey are disqualified by teachers, and acquisitions based on democracy education in the curriculums which are prepared and implemented in the secondary schools in Austria are found adequate by teachers. Acquisitions and values for democracy education in the secondary schools in Austria are transferred to the students mostly by basing on social learning theory. Though in Turkey teachers are lack of qualification about the democracy education intended to transfer attributes to the students, it is stated that there aren't many cases in Austria those like in Turkey. It was observed that the contents within curriculums prepared for democracy education in Turkey was not enough but in Austria the content was enough. It is defined that democracy education in Turkey is mostly oriented to the values;
\end{abstract}

* Bu çalışma İkinci yazarın İnönü Üniversitesi Eğitim bilimleri Enstitüsü Sosyal Bilgiler Öğretmenliğinde yapmış olduğu yüksek lisans tezinden üretilmiştir. 
however, in Austria for the knowledge.

Keywords: Democracy, Democracy Education, Social Studies Education

\section{GİRİ̧̧}

Halk "demos" ve egemenlik "kratos" sözcüklerinden oluşan demokrasi kavramının tarihsel süreçte kullanımı Antik Atina’ya dayanmaktadır. Demokrasi kavramının kelime yapısından da anlaşıldığı gibi halkın kendi kendini yönetmesi veya halkın siyasal iktidarda egemen olması anlamına gelmektedir. Tarihsel süreçte demokrasi ilk başlarda sadece siyasal yönetimler için kullanılırken zaman içindeki değişim ile toplumsal yaşam ile bireysel tutum ve davranışlarıda kapsamıştır (Dewey, 2010; Leser, 2011).

Demokrasi kavramı ile ilgili bir çok farklı tanımlamalar yapılmıştır. Bu yapılan tanımlamaların bazılarında demokrasi bir yönetim şekli olarak diktatör rejimler yada monarşik krallıklar yerine halkın iktidar olup devletin halk tarafindan yönetilmesi olarak (Başgil, 2006; Çam , 2002; Hobbes, 2007; Kışlalı, 1987; Saray, 1999; Tanilli, 1996; Weiss, 2010; Yıldırım, 2004) ifade edilirken; bazı tanımlamalarda demokrasi tüm toplum bireylerinin eşit olduğu, kişin hakve özgürlüklerinin anayasalar tarfindan korunduğu, herkesin seçme ve seçilme hakkı olduğu ve insan haklarının ön planda olduğu siyasal rejimler (Beetham ve Boyle,1998; Dağı ve Polat, 1999; Dahl, 2000; Eley, 2008; Gözübüyük, 2007; Uygun, 2003; Yılman, 2006) olarak belirtilmiştir. Demokrasi bir yönetim şekli olmakla birlikte aynı zamanda bireye özgürlükler ve haklar vererek toplumun diğer fertleri gibi eşit olma hakkı tanır. Demokrasi ile birey seçme ve seçilme hakkının olduğunu kavrar. Aynı zamanda demokrasi bireylerin eşit haklarının olmasından dolayı toplum içinde bir arada hoşgörü içinde yaşama olanağı sağlar.

Siyasal yönetimler içinde bireye en fazla değeri demokrasi verir. Demokrasi kişileri din, dil, ırk ve cinsiyet ayrımı yapmadan özgür bir şekilde yaşamasını amaçlar ( Duman, Karakaya \& Yavuz, 2001; Kozaner, 2012). Aynı zamanda demokrasi bireyin toplum ve devlet ile olan ilişkilerini düzenleyerek bireyin haklarını korur (Üste, 2011). Fakat demokrasinin ortaya çıkışı birden bire olmayıp zaman içinde gelişerek toplumlara yerleşir. Bir toplumun demokratik olabilmesi için ise şu özelliklerinin olması gerekmektedir:

- Demokratik bir toplumda kişi hak ve hürriyetleri yasalar ile güvenceye alınmıştır,

- Toplum fertleri, bireysel ve siyasal hayatları ile ilgili tercih yapma hakkına sahiptirler,

- Sosyal ve siyasal süreçlerin tüm kısımlarında bireyler yer alabilirler,

- Demokratik seçimlerle gelmiş siyasal bir yönetimin en öneml vazifesi, yurttaşlarının ekonomik ve sosyal güvenliğini sağlamaya çalışmaktır,

- Siyasal süreçlerle seçilmiş olan temsicilerin, yurttaşlara gerektiğinde hesap verebilmesi gerekir,

- Yurttaşlar bütün demokratk kurumlardan bilgi edinebilir ve bilgi paylaşabilir,

- Bütün yurttaşlar kendilerini özgürce ifade edebilme, bireysel olarak kendilerini geliştirme ve yaratıcılıklarını kullanabilme haklanına sahiptirler (Şişman, 2006).

Demokrasinin toplum içinde benimsenmesinin en önemli yolu eğitimdir. Demokrasi eğitimi ile öğrencilere demokrasi düşüncesi kazandırılmaktadır. Demokrasi eğitimi, insan hak ve özgürlüklerinin, demokrasinin temel ilkeleri ve kurallarının eğitim programlarında örtük veya açık bir şekilde verilmesi ile öğrencilerin demokrasi ile ilgili kazanımlara sahip olmasını hedefler (Hotaman, 2010; Kozaner, 2012). Bu hedef doğrultusunda demokrasi eğitimi ile öğrencilerde, düşünebilme ve düşündüklerini özgürce dile getirebilme becerisi geliştirilmesi sağlanır. Ayrıca öğrencilerin kendi düşüncelerini faklı görüşlere saygı duyarak düzgün ve özlü bir şekilde ifade edebilmesi demokrasi eğitimiyle gerçekleşir (Yeşil, 2003).

Bir toplumda demokrasi bilincinin oluşabilmesi, demokrasi eğitimi içerikli konuların eğitim programlarında daha çok yer verilmesi ile mümkündür. Bu yüzden demokrasi eğitimi içerikli konular toplumun ve öğrencilerin ihtiyaçları dikkate alınarak hazırlanmalı ve tüm eğitim sürecine serpiştirilerek öğrenciye kazandırılması sağlanmalıdır. Aynı zamanda demokrasi eğitimine yönelik içerik ve kazanımlar belirlenirken 
farklı demokratik ülkelerdeki demokrasi eğitimine yönelik program ve uygulamaların dikkate alınması, hem farklı bir bakış açısı ve hemde demokrasi bilinci kazandırmada en iyi eğitimi sunmada başarılı olabilir. Bu nedenle farklı ülkelere ait eğitim programlarında yer alan demokrasi eğitimi kazanım ve içeriklerini incelemek ülkemizin sahip olduğu demokrasi eğitiminin güncellenmesine olanak sağlar. Bu araştırma ile Avusturya ve Türkiye'deki ortaokullarda eğitim programlarında yer alan demokrasi eğitimi içeriklerinin benzerlik ve farklılıkları öğretmen görüşleriyle belirlenerek yeterliliğininin karşılaştırılması amaçlanmıştır.Bu amaç doğrultusunda aşağıdaki sorulara cevap aranmıştır:

$\checkmark$ Avusturya ve Türkiye'deki öğretmenler demokrasi eğitimini nasıl tanımlamaktadırlar?

$\checkmark$ Avusturya ve Türkiye'deki öğretmenlere göre, demokrasi eğitimine yönelik olarak ortaokul kademesi için hazırlanan programlarda yer verilen kazanımlar yeterli midir?

$\checkmark$ Avusturya ve Türkiye’deki öğretmenlere göre, ortaokul kademesinde demokrasi eğitimine yönelik olarak verilen içerik kapsam olarak yeterli midir?

$\checkmark$ Avusturya ve Türkiye'deki öğretmenlere göre, ortaokul kademesinde demokrasi eğitimine yönelik olarak verilen içeriğin aktarımında öğretim ilkelerine, (bilinenden bilinmeyene, kolaydan zora, basitten karmaşığa, yakından uzağa ilkeleri gibi) uyulmakta mıdır?

$\checkmark$ Avusturya ve Türkiye'deki öğretmenlere göre, demokrasi eğitimi kapsamında ortaokul kademesinde işlenen konular bilgi veya değer kazandırmaktan hangsine yöneliktir?

\section{YÖNTEM}

\subsection{Araştırmanın Modeli}

Araştırma nitel araştırma yöntemlernden durum çalışması temelli şekillenmiştir. Durum çalışmalarında, bir durum ile ilgili etkili olan tüm faktörler (kişiler,olaylar,ortam, süreçler v.b) bütüncül bir yaklaşımla araştırılarak, etkenlerin durumu nasıl etkilediklerini ve bu durumdan nasıl etkilenmiş oldukları derinlemesine incelenir (Hancock, 1998; Yıldırım \& Şimşek, 2008).

\section{2. Çalışma Grubu}

$\mathrm{Bu}$ araştırmanın çalışma grubunu Diyarbakır il merkezinde yer alan ortaokullarda görev yapan sosyal bilgiler öğretmenleri ile Viyana şehir merkezinde yer alan ortaokullarda görev yapan 100 tarih ve sosyal bilgiler öğretmenleri oluşturmaktadır. Araştırmada, çalışma grubunun seçilmesinde amaçlı örnekleme yöntemi kullanılmıştır. Katılımcı öğretmenlere ilişkin demografik özeellikler Tablo 1'de verilmiştir.

Tablo 1. Katılima ögretmenlere iliskin bilgiler

\begin{tabular}{|c|c|c|c|c|c|}
\hline \multirow[t]{2}{*}{ Demografik Özellikler } & & \multicolumn{2}{|c|}{$\begin{array}{c}\text { Çalışma Grubu } \\
\text { Türkiye }\end{array}$} & \multicolumn{2}{|c|}{$\begin{array}{c}\text { Çalışma Grubu } \\
\text { Avusturya }\end{array}$} \\
\hline & & $\mathrm{N}$ & $\%$ & $\mathrm{~N}$ & $\%$ \\
\hline \multirow{2}{*}{ Cinsiyet } & Kadın & 20 & 40 & 28 & 56 \\
\hline & Erkek & 30 & 60 & 22 & 44 \\
\hline \multirow{3}{*}{ Yaş } & 30 ve alt1 & 7 & 14 & 5 & 10 \\
\hline & 31-41 aras1 & 21 & 42 & 23 & 46 \\
\hline & 41 ve üstü & 22 & 44 & 22 & 44 \\
\hline \multirow{4}{*}{ Mesleki Kıdem } & $1-5$ y1l & 7 & 14 & 7 & 14 \\
\hline & $6-10 \mathrm{y} 1 \mathrm{l}$ & 13 & 26 & 10 & 20 \\
\hline & $11-15$ y1l & 20 & 40 & 23 & 46 \\
\hline & 16 ve üstü & 10 & 20 & 10 & 20 \\
\hline \multirow{3}{*}{ Eğitim Düzeyi } & Önlisans & - & - & 15 & 30 \\
\hline & Lisans & 32 & 64 & 29 & 58 \\
\hline & Lisansüstü & 18 & 36 & 6 & 12 \\
\hline
\end{tabular}

Türkiye'deki katılımcıların demografik özelliklerine ilişkin Tablo 1'e bakıldığında çalıs̆ma grubunu oluşturan öğretmenlerin \%40'ını kadınların ve \%60'ını ise erkeklerin oluşturduğu görülmektedir. Demografik özelliklerde, öğretmenlerin yaşına bakıldığında \%14’ü 30 ve otuzun altı, \%42’si 31-41 arası ve \%44’ü ise 41 ve üstü yaşta bulunmaktadır. Öğretmenlerin mesleki kıdemlerine bakıldığında \%14'ü 1-5 yıl, \%26's1 6-10 yıl, 
\%40’111-15 yıl, \%20’si ise 16 ve üstü yıla sahip olduklarını belirtmişlerdir. Eğitim düzeyi olarak öğretmenlerin \%64'ü lisans ve \%36'sı ise lisansüstü eğitim aldıklarını ifade etmektedir..

Avusturyadaki katılımcıların demografik özelliklerine ilişkin Tablo 1'e bakıldığında çalışma grubunu oluşturan öğretmenlerin \%56'sını kadınlar ve \%44'ünü ise erkeklerin oluşturduğu görülmektedir. Demografik özelliklerde, öğretmenlerin yaşına bakıldığında \%10’u 30 ve otuzun altı, \%46's1 31-41 arası ve \%44’ü ise 41 ve üstü yaşta bulunmaktadır. Öğretmenlerin mesleki kıdemlerine bakıldığında \%14’ü 1-5 yıl, \%20'si 6-10 yıl, \%46'sı 11-15 yıl, \%20'si ise 16 ve üstü yıla sahip olduklarını belirtmişlerdir. Eğitim düzeyi olarak öğretmenlerin $\% 30$ ’u önlisans, \%58'i lisans ve \%12'si ise lisansüstü eğitim aldıklarını ifade etmektedir (Avusturya'da ön lisans kastedilen ilk ve ortaöğretim I. devre öğretmenlerinin bir Öğretmen Eğitim Kolejinde 3 y1llık bir eğitim almış olmalarıdır).

\subsection{Veri Toplama Arac1}

Türkiye ve Avusturya'daki tarih ve sosyal bilgiler öğretmenlerinin demokrasi eğitimine ilişkin görüşlerini belirlemek amacıyla beş açık uçlu sorudan oluşan yarı yapılandırılmış görüşme formu kullanılmıştır. .(görüşme sorularının araştırmanın amacına uygun olup olmadığını beirlemek amacıyla alan uzmanı dört akademisyen ve bir sosyal bilgiler öğretmeninin görüşlerine başvurulmuştur. Böylelikle görüşme soruların kapsam geçerliliği sağlanmaya çalışılmıştır. Daha sonra araştırmacı tarafından oluşturulan beş açık uçlu soru(nun), anlaşılırlığının tespiti için sosyal bilgiler öğretmenlerinin görüşleri alınmış gerekli düzeltmeler yapılarak görüşme formuna son şekli verilmiştir.

\subsection{Verilerin Analizi}

Çalışmada katılımcı öğretmenlerin demokrasi eğitimine ilişkin görüşlerini almak için hazırlanan yarı yapılandırılmış görüşme formundan elde edilen verilerle içerik analizi yapılmıştır. İçerik analizinde çalışma grubunu oluşturan öğretmenlerin bazı ifadelerine yer verilmiş ve ifadelerde yer alan temel noktalar; yüzde, frekans değerleri göz önüne alınarak incelenmiştir. İçerik analizi sürecinde, tümevarımcı bir anlayış ile öğretmenlerin görüşleri değerlendirilmiş olup alt kodlardan temalara ulaşılmıştır. Öncelikli olarak tüm kodlamalar aralıksız bir biçimde tamamlandıktan sonra temalara ulaşma sürecinde ise iki hafta sonra görüşler ve kodlamalar yeniden yapılıp (kontrol edilip) önceden bulunan kodların uyuşup uyuşmadığı kontrol edilmiş ve böylece nitel verilerin güvenirliği sağlanmaya çalışılmıştır. Kodlama sürecinde Türkiye'deki katıllımcılar için ' $T$ ' Avusturya' daki katılımcılar için ise 'A' harfi kullanılmıştır.

\section{BULGULAR}

$\mathrm{Bu}$ bölümde, toplanan verilerin çözümlenmesi sonucu elde edilen bulgular ve bu bulgular doğrultusunda yapılan yorumlar bulunmaktadır. Bulgular kısmında ise toplanan bu veriler bütüncül bir biçimde ele alınmıştır. Bulgular ve yorumlar beş ana başlık altında verilmiştir.

\subsection{Demokrasi Eğitiminin Tanıma ilişkin elde edilen bulgular}

Avusturya ve Türkiye'deki katılımcı öğretmenlere demokrasi eğitiminin tanımına ilişkin "Demokrasi eğitimi denilince ne anliyorsunuæ" sorusu sorulmuştur. Bu soruya ilişkin öğretmenler tarafindan verimiş olan yanıtlar sonucunda elde edilmiş olan verilerin frekans ve yüzde değerleri tablo 2'de verilmiştir. 
Tablo 2. Katılımo Öğretmenlerin Demokrasi Kavramına Ilişkin Görüsleri

\begin{tabular}{|c|c|c|c|c|c|}
\hline Türkiye Alt Temalar & f & $\%$ & Avusturya Alt Temalar & f & $\%$ \\
\hline G.1Bireysel ifade özgürlüğü & 6 & 12 & $\begin{array}{l}\text { G.1Bireyin kendi kendisini yönetme } \\
\text { yetkisine sahip olmas1 }\end{array}$ & 6 & 12 \\
\hline G.2Eşitsel düzeyde eğitim & 4 & 8 & G.2Bireysel farklilıklara sayg1 & 4 & 8 \\
\hline G.3 Kurallara saygilı anlayış & 4 & 8 & G.3 Kurallara saygılı anlayış & 4 & 8 \\
\hline G.4 Özgürlükçü anlayış & 8 & 16 & G.4 Özgürlükçü anlayış & 8 & 16 \\
\hline G.5 İnsan haklarina sayg1 & 8 & 16 & G.5 İnsan haklarına sayg1 & 10 & 20 \\
\hline G.6 İfade özgürlüğü & 12 & 24 & G.6 İfade özgürlüğü & 18 & 36 \\
\hline G.7 Toplumsal yaşama uyum & 6 & 12 & & & \\
\hline G.8 Yönetimde özgürlük & 2 & 4 & & & \\
\hline Toplam & 50 & 100 & Toplam & 50 & 100 \\
\hline
\end{tabular}

Türkiye ve Avusturya'daki katılımc1 öğretmenlerin "Demokrasi eğitimi denilince ne anlyorsunuq??" şeklindeki soruya birbirinden farklı yanıtlar verdikleri Tablo 2'de görülmektedir. Türkiye'deki öğretmenlerin bu soruya birbirinden farklı yanıtlar verdiği görülse de sayısal olarak öğretmenlerin büyük bir kısmının üzerinde birleştikleri alt temanın \%24 ile "ifade özgürlüğü” olduğu gözlemlenmektedir. Daha sonra katılımcılar \%16 ile “ Özgürlük anlayışı” ve "İnsan haklarına saygı” alt temalarında birleştikleri görülmektedir. Avusturya'daki katılımcıların vermiş oldukları yanıtlar ise birbirinden farklı olsada, öğretmenlerin büyük bir kısmının \% 36 ile “ifade özgürlügüu” alt temasında ve \% 20 ile "İnsan haklarına sayg1” alt temasında birlştikleri görülmektedir.

Türkiye ve Avusturyadaki katılımcı öğretmenlerin "Demokerasi eğitimi denilince ne anlyyorsunu₹?" şeklindeki soruya ilişkin vermiş oldukları cevaplardan, bazılarının görüşleri aşağıda verilmiştir:

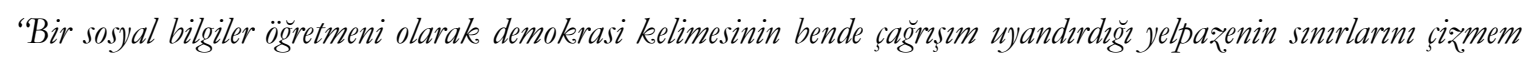
mümkïn değildir. Ancak bu yelpaze içerisinde demokrasinin bende çağrrş̧ım uyandirdiğ en önemli ifade, özgür bir ortamda yaşama dayah olarak bireyin özgür benlï̈ini oluşturmasıdır.” (G.4 T)

"51 yaşında olan bir ögretmen olarak, benim demokrasiden anladiğgm ile ülkemizdeki demokrasiden anlamam

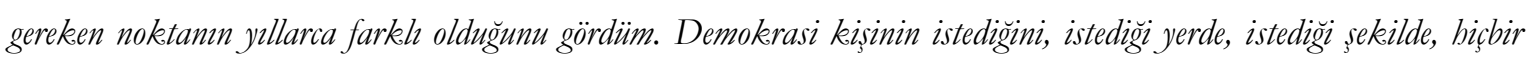
basker altında kalmadan bence söyleyebilmesidir."(G.1 T)

"Demokrasi kelimesi, bana göre her kişinin öz benine göre şekillenir. Bundan dolay demokrasi bireyin öncelikle kendisini tanması, kendisine karşı gösterdiği değerdir. Kendisine değger veren birey toplum içerinde yer alan insan olgusuna da sayg gösterir. Bireyin rengi, dili, dini ve ırke ne olursa olsun bu saygı kavramı değğsmemelidir.”(G.2 A)

Öğretmenlerin vermiş olduklara cevaplara bakıldığında demokrasi eğitimi için tek bir tanımın olmadığı görülmektedir. Öğretmenler demokrasi eğitimini genel olrak ifade özgürlüğ, insan haklarına sayg1 ve özgürlük anlayışı olarak belirtmişlerdir.

\subsection{Demokrasi eğitimine yönelik olarak ortaokul kademesi için hazırlanan programlarda yer verilen kazanımlara İlişkin bulgular}

Avusturya ve Türkiye’deki katılımcı öğretmenlere ortaokul kademesi için hazırlanan programlarda yer verilen kazanımlara ilişkin "Demokrasi eğitimine yönelik olarak ortaokul kademesi için hažrlanan programlarda yer verilen kazanimlar yeterli buluyor musunuz? Neden?” sorusu sorulmuştur. Bu soruya ilişkin öğretmenler tarafindan verimiş olan yanıtlar sonucunda elde edilmiş olan verilerin frekans ve yüzde değerleri tablo 3'de verilmiştir. 
Tablo 3. Ortaokul kademesi için hąurlanan programlarda yer verilen kazanmmlara ilişkin görüsler

\begin{tabular}{|c|c|c|c|c|c|}
\hline & \multicolumn{5}{|c|}{$\begin{array}{l}\text { 2.TEMA: Demokrasi eğitimine yönelik olarak, ortaokul kademesi için hą̧rlanan programlarda yer verilen } \\
\text { kazanmlar }\end{array}$} \\
\hline & & Alt Temalar & & $\mathrm{f}$ & $\%$ \\
\hline \multirow{10}{*}{ 逽 } & \multirow{4}{*}{ Evet } & G.1 Demokratik değerlerin model yoluyla öğrenilmesi & & 2 & 4 \\
\hline & & G.2 Öğretmenlerin uygulamadaki yetersizlikleri & & 2 & 4 \\
\hline & & G.3Öğrenciyi teorik olarak bilgiye boğmama & & 3 & 6 \\
\hline & & G.4Diğer disiplinlerde de bu kazanımlara yer verilmesi & & 3 & 6 \\
\hline & \multirow{5}{*}{ Hayir } & G.5Hazır bulunuşluk eksikliği & & 6 & 12 \\
\hline & & G.6Tek tip düşünceye dayalı eğitim & & 10 & 20 \\
\hline & & G.7 Somutlaştırma eksikliği & & 7 & 14 \\
\hline & & G.8 Teorik olarak sadece yeterlilik & & 8 & 16 \\
\hline & & G.9Öğrenci düzeyine uygun olmamas1 & & 9 & 18 \\
\hline & & & Toplam & 50 & 100 \\
\hline \multirow{6}{*}{ 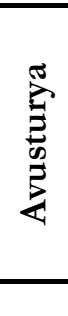 } & \multirow{3}{*}{ Evet } & G.1 Demokratik değerlerin gözlem yoluyla öğrenilmesi & & 22 & 44 \\
\hline & & G.2 Öğretmenlerin alan yeterlilikleri yetersizlikleri & & 2 & 4 \\
\hline & & G.3Öğrenciyi teorik olarak bilgiye boğmama & & 16 & 32 \\
\hline & \multirow{2}{*}{ Hayır } & G.4Tek tip birey & & 3 & 6 \\
\hline & & G.5Somutlaştırma eksikliği & & 7 & 14 \\
\hline & & & Toplam & 50 & 100 \\
\hline
\end{tabular}

Tablo 3' e bakıldığında Türkiye ve Avusturya'daki katılımc1 öğretmenlerin "Demokrasi eğitimine yönelik. olarak ortaokul kademesi için bą̧ılanan programlarda yer verilen kaz̧anmlar yeterli buluyor musunuə?? Neden?” şeklindeki soruya birbirinden farklı yanıtlar verdikleri görülmektedir. Türkiye'deki öğretmenlerin büyük bir kısmının yeterli bulmadığ1 ve \%20 ile “Tek tip düşünceye dayalı eğitim” alt temasında birleştikleri görülmektedir. Avusturya'daki katılımcıların ise büyük bir kısmının yeterli bulduğu ve \%44 ile "Demokratik değerlerin gözlem yoluyla öğrenilmesi” alt temasında birleştikleri görülmektedir.

Türkiye ve Avusturyadaki öğretmenlerin 'Demokrasi eğitimine yönelik olarak ortaokul kademesi için haz̧rlanan programlarda yer verilen kazanmmlar yeterli buluyor musunuz? Neden?"şeklindeki soruya ilişkin vermiş olduklan cevaplardan, bazılarının görüşleri aşağıda verilmiştir:

"Ortaokul kademesinde yer alan programlarda demokrasi eğitimine yönelik. kazanmmlar nicelik olarak yeterli olduğn görülse de aslanda yetersiżir. Cünkü ortaokul programlarnnda yer alan kazanumlarn bu kademede yer alan ögrencilerin seviyesine uygun olmadĭg düş̈̈ncesindeyim. ”(G.9 T)

"Ortaokul kademesi için haz̧rlanan programlarda demokrasi eğitimine yönelik olarak verilen kazanumlar yeterli buluyorum. Demokratik değerlerin bana göre teorik etkinliklerden ziyade ögrrenciye demokratik değerleri içeren davramışlarm model olarak sergilenmesi ile kazanderlacă̆g düs̈̈̈ncesindeyim. ”(G.1 T)

"Ben bir tarih ve sosyal bilgiler ögretmeniyim, ama ortaokul kademesinde demokrasi eğitimine ilişkin aym bir disiplin program ülkemizde göremiyorum. Ancak konu ile ilgili diğer disiplinlerde verilen kazanmmlar yeterli buluyorum. Cünkü bu konuda ögrenciyi fazla bilgiye boğmak yerine ögrenciye herhangi bir olay karşında anti demokratik ve

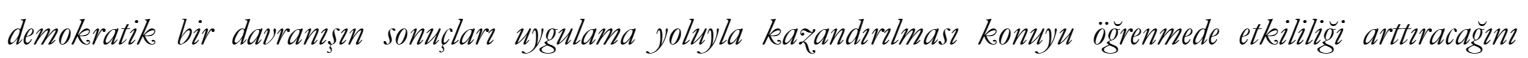
düşünüyorum. '(G.1 A)

"Ortaokul kademesi için hažrlanan programlara baktiğmida demokrasi eğitimine yönelik olarak kazanmlarn uygulama basamă̆gn da kapsadĭğ programlarda görülmektedir. Ancak bu basamăga yönelik olarak yapılacak. etkinlikler öğretmenin mesleki yeterliliğ ve okulun sunduğu olanaklara bağh olduğundan somutlaştrma anlamında bir takım sıkintılar yaşanmaktadir. Ben bundan dolayn yetersiz buluyorum.”(G.5 A)

Türkiyedeki öğretmenlerin ortaokul kademesi için hazırlanan programlarda yer verilen kazanımları yeterli bulmadıkları ve kazanımlarda sonutlaştırmanın eksikliğinin olduğu ve tip düşünceye dayalı eğitime yönelik olduğu belirtilmiştir. Avusturya'daki öğretmenler ise kazanımları genel olrak yeterli buldukları ve bu kazanımlar ile ilgili demokratik değerlerin gözlem yoluyla öğrenilmesi gerektiğini belirtmişlerdir. 


\subsection{Ortaokul kademesinde demokrasi eğitimine yönelik olarak verilen içeriğe ilişkin bulgular.}

Avusturya ve Türkiye'deki katılımcı öğretmenlere ortaokul kademesinde demokrasi eğitimine yönelik olarak verilen içeriğe ilişkin "Ortaokul kademesinde demokrasi eğitimine yönelik olarak verilen içeriği kapsam olarak yeterli buluyor musunuz? Neden? sorusu sorulmuştur. Bu soruya ilişkin öğretmenler tarafindan verimiş olan yanıtlar sonucunda elde edilmiş olan verilerin frekans ve yüzde değerleri tablo 4'de verilmiştir:

Tablo 4. Ortaokul kademesinde demokrasi eğitimine yönelik olarak verilen içeriğe ilişkin Görü̈sler

\begin{tabular}{|c|c|c|c|c|}
\hline & & Alt Temalar & f & $\%$ \\
\hline \multirow{6}{*}{ 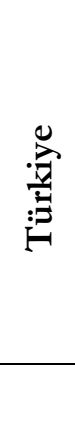 } & \multirow[t]{3}{*}{ Evet } & G.1 Birbirinden farklı birden çok konunun yer alması & 4 & 8 \\
\hline & & G.2 Öğrenme çeşitliliğindeki zorunluluk & 6 & 12 \\
\hline & & G.3 Konunun uygulama alanı eksikliği & 16 & 32 \\
\hline & \multirow[t]{2}{*}{ Hayir } & $\begin{array}{l}\text { G.4 Teorik olarak yeterli olup uygulama alanı bakamından eksik } \\
\text { olması }\end{array}$ & 16 & 32 \\
\hline & & G.5 Konunun gerçek yaşamla ilişkilendirilme eksikliği & 8 & 16 \\
\hline & & Toplam & 50 & 100 \\
\hline \multirow{6}{*}{ 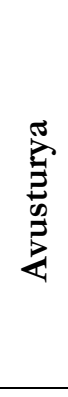 } & & Alt Temalar & $\mathrm{f}$ & $\%$ \\
\hline & \multirow[t]{3}{*}{ Evet } & G.1 Birbirinden farklı birden çok konunun yer alması & 8 & 16 \\
\hline & & G.2Farklı öğrenme alanlarının sağladığı katk1 & 20 & 40 \\
\hline & & G.3 Konunun uygulama alanı eksikliği & 16 & 32 \\
\hline & \multirow[t]{2}{*}{ Hayır } & G.4Davranışa dönüşüm eksikliği & 2 & 4 \\
\hline & & G.5Uygulanabilirlik eksikliği & 4 & 8 \\
\hline & & Toplam & 50 & 100 \\
\hline
\end{tabular}

Türkiye ve Avusturya'daki katılımcı öğretmenlerin "Ortaokul kademesinde demokrasi eğitimine yönelik olarak verilen içeriği kapsam olarak yeterli buluyor musunų? Neden ?’ şeklindeki soruya birbirinden farklı yanıtlar verdikleri Tablo 4'de görülmektedir. Türkiye'deki öğretmenlerin bu soruya birbirinden farklı yanıtlar verdiği görülse de istatistiksel olarak öğretmenlerin büyük bir kısmının yeterli buldukları ve \%32 ile "Konunun uygulama alanı eksikliği”alt temasında birleştikleri görülmektedir.. Avusturya'daki katılımcıların vermiş oldukları yanıtlar ise birbirinden farklı olsada, öğretmenlerin büyük bir kısmının yeterli buldukları ve \% 40 ile "Farklı öğrenme alanlarının sağladığı katkı” alt temasında birleşmişlerdir.

Türkiye ve Avusturyadaki öğretmenlerin "Ortaokul kademesinde demokrasi eğitimine yönelik olarak verilen içeriğgi kapsam olarak yeterli buluyor musunuz? Neden?"şeklindeki soruya ilişkin vermiş oldukları cevaplardan, bazılarının görüşleri aşağıda verilmiştir:

"Demokrasi eğitimine iliskin ortaokul programlarn yer verilen içeriği 15 ynlllk. bir öğretmen olarak yeterli buluyorum.

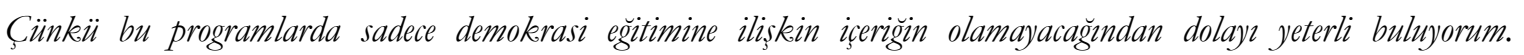
Ortaokul kademesinde alan seçimi öncesi kademe olduğundan dolayı temel derslere yönelike bütün içeriği de kapsaması gerekliliği unutulmamalidrr."(G.1 T)

"Ortaokul kademesinde demokrasi eğitimi dışında birbirinden farklı disiplinlere ait kazanmmlar yer aldiğgndan dolayı bence demokerasi eğitiminin programlarda yer alan kazanmlarm yeterli buluyorum. Bu programlarda da birbirinden farkh disiplinlere ait kazanmlarn yer almasın öğrenciler için bir ibtiyaç olarak görüyorum.’'

'”(G.1 A)

Türkiye'deki katılımcılardan demokrasi eğitimi içeriğini yeterli bulan çalışma grubu öğretmen görüşüne göre, içerik temel derslere yönelik olarak bütün içeriği kapsaması gerekirken; Demokrasi eğitimi içeriğini yetersiz bulan çalışma grubu öğretmen görüşüne göre, içerik sadece bilgi basamağına yönelik değil, uygulama basamağına yönelik becerileri de kapsadığı takdirde yeterli olacağı belirtilmiştir. Avusturya'daki katılımcı öğretmen görüşlerine göre, farklı disiplinlere ait kazanımlar yer aldığından ve teorik olarak içerik yeterli görülürken; Demokrasi eğitimi içeriğini yetersiz bulan çalışma grubu öğretmen görüşüne göre, içeriğin öğrenci davranışları üzerinde değişikliğe yol açmadığından yetersizdir. 
3.4. Ortaokul kademesinde demokrasi eğitimine yönelik olarak verilen içeriğin aktarımına ilişkin bulgular

Avusturya ve Türkiye'deki katılımcı öğretmenlere ortaokul kademesinde demokrasi eğitimine yönelik olarak verilen içeriğin aktarımına ilişkin "Ortaokul kademesinde demokerasi eğitimine yönelik olarak verilen içeriğin aktarmmnda ögretim ilkelerine, (bilinenden bilinmeyene, kolaydan zora, basitten karmaşı̆ga, yakından uză̆a ilkeleri gibi) uyulmakta mıdır? Neden?” sorusu sorulmuştur. Bu soruya ilişkin öğretmenler tarafindan verimiş olan yanıtlar sonucunda elde edilmiş olan verilerin frekans ve yüzde değerleri tablo 5'de verilmiştir:

Tablo 5. Ortaokul kademesinde demokrasi eğitimine yönelik olarak verilen içeriğ̈in aktarmmna ilişkin görüsler

4.TEMA: Ortaokul kademesinde demokrasi eğitimine yönelik olarak verilen içeriğin aktarımı

\begin{tabular}{|c|c|c|c|c|c|}
\hline \multirow{7}{*}{ 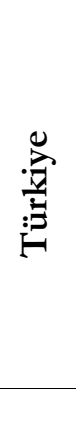 } & & Alt Temalar & & f & $\%$ \\
\hline & \multirow[t]{4}{*}{ Evet } & G.1 Bilginin daha kolay anlamlandırılmas1 & & 12 & 24 \\
\hline & & G.2 Modüler öğrenmeyi sağlama & & 11 & 22 \\
\hline & & G.3 Öğrenmede birikimli olarak ilerleme & & 13 & 26 \\
\hline & & G.4 Öğrencinin derse katılımını sağlama & & 9 & 18 \\
\hline & \multirow[t]{2}{*}{ Hayır } & G.5Ders süresinin yeterli olmamas1 & & 5 & 10 \\
\hline & & & Toplam & 50 & 100 \\
\hline \multirow{7}{*}{ 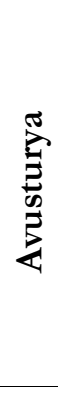 } & & Alt Temalar & & f & $\%$ \\
\hline & \multirow{3}{*}{ Evet } & G.1 Anlamlı öğrenme & & 9 & 18 \\
\hline & & G.2 Küçük adımlar & & 13 & 26 \\
\hline & & G.3 Aktif katillim & & 20 & 40 \\
\hline & \multirow{2}{*}{ Hayır } & G.4 Bireysel farkliliklar & & 5 & 10 \\
\hline & & G.5 Materyal kullanma yeterliliğinin eksikliği & & 3 & 6 \\
\hline & & & Toplam & 50 & 100 \\
\hline
\end{tabular}

Tablo 5'e bakıldığında Türkiye ve Avusturya'daki katılımcı öğretmenlerin “Ortaokul kademesinde demokrasi eğitimine yönelik olarak verilen içeriğin aktarmmnda ögretim ilkelerine, (bilinenden bilinmeyene, kolaydan zora, basitten karmaşı̆̆a, yakından u₹ăga ilkeleri gibi) uyulmakta mıdır? Neden?” şeklindeki soruya birbirinden farklı yanıtlar verdikleri görülmektedir. Türkiye'deki öğretmenlerin büyük bir kısmının evet dediği ve \%26 ile "Öğrenmede birikimli olarak ilerleme” alt temasında birleştikleri görülmektedir. Avusturya'daki katılımcı öğretmenlrinde büyük bir kısmının evet dediği ve \%40 ile "Aktif katılım” alt temasında birleştikleri görülmektedir.

Türkiye ve Avusturyadaki öğretmenlerin "Ortaokul kademesinde demokrasi eğitimine yönelik olarak verilen içeriğgin aktarmmnda ögretim ilkelerine, (bilinenden bilinmeyene, kolaydan zora, basitten karmaşı̆a, yakından uহağa ilkeleri gibi) uyulmakta mıdır? Neden?’”'şeklindeki soruya ilişkin vermiş oldukları cevaplardan, bazılarının görüşleri aşağıda verilmiştir:

“Ortaokul kademesinde demokrasi eğitimine yönelik olarak verilen içeriğin aktarmmnda ögretim ilkelerine uyulması

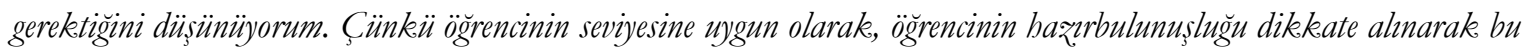
ilkelere göre ders anlatılırsa ögrencinin derse katıllmu artacaktır. "(G.4 T)

"Yillarder ders anlatan bir ögretmen olarak, ben sadece demokrasi içeriğine ait konularda değgil bütün konularda ögretim ilkelerine uyularak ders anlatılamayacă̆ı kanısındayım. Cü̈nkü ögretmenin bunu uygulaması için ekstra ders süresine ibtiyacı olacağın düş̈̈n̈̈yorum."'(G.5 T)

"Demokrasi eğitimine yönelik içeriğgin aktarmmnda ögretim ilkelerine uyulduğgnda öğrencinin öğrenme güdüsünün artmast ile birlikte derse katıllm da artacaktır. Bu durumda ögrenci merkęli çok katuliml bir ögrenme ortammm olusmasin sağlayacaktır."'(G.3 A)

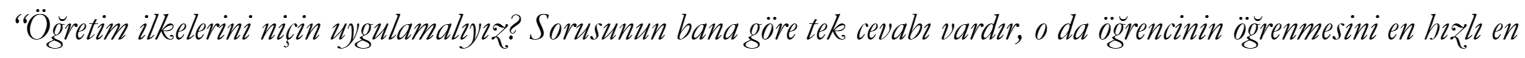
anlamlı ve kahcu şekilde sağlamaktur. Ancak burada her zaman her sinifta yer alan ögrencilerin konu ile ilgili ön 
koşul ögrenmeleri birbirinden farkh olduğundan dolayı bu ilkelerin uygulanmasina ben bir ögretmen olarak. karşıım."(G.4 A)

Türkiye'deki öğretmenler, ortaokul kademesinde demokrasi eğitimine yönelik olarak verilen içeriğin aktarımında öğretim ilkelerine uyulması gerektiğini, böylece öğrenci seviyesine uygun ve hazır bulunuşluğu dikkate alınarak ders işlendiğinde, öğrencinin konuyu anlaması ve kalıcı olmasında etkili olabileceği ifade etmişlerdir. Avusturya'daki öğretmenlerde ortaokul kademesinde demokrasi eğitimine yönelik olarak verilen içeriğin aktarımında öğretim ilkelerine uyulması gerektiğini ifade edip bir konu tam öğretilmeden diğerine geçilmemesi gerektiğini ve öğrenciye görelilik ilkesine dikkate alınarak çok katılımlı bir öğrenme ortamının oluşması gerektiği belirtilmiştirler.

\subsection{Avusturya'daki Çalışma Grubu Öğretmenlerinin Demokrasi Eğitiminde Yer Verilen İçeriğin} Amacına İlişkin Bulgular

Avusturya ve Türkiye'deki katılımcı öğretmenlere ortaokul kademesinde demokrasi eğitimine yönelik olarak verilen içeriğin amacina ilişkin "Demokrasi eğitimi kapsammda ortaokul kademesinde işlenen konularn değerlere mi yoksa bilgiye dönüle olması ile ilgili neler düşünüyorsunų? Niçin?” sorusu sorulmuştur. Bu soruya ilişkin öğretmenler tarafından verimiş olan yanıtlar sonucunda elde edilmiş olan verilerin frekans ve yüzde değerleri tablo 6'da verilmiştir:

Tablo 6. Demokrasi eğitiminde yer verilen içeriğin amacına ilişkin görüşler

\begin{tabular}{|c|c|c|c|c|c|}
\hline \multirow{5}{*}{ 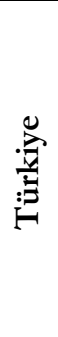 } & & Alt Temalar & & $\mathrm{f}$ & $\%$ \\
\hline & \multirow{2}{*}{$\begin{array}{l}\text { Değer } \\
\text { temellidir }\end{array}$} & G.1 Programda yer alan işlevsellik ve hayatilik ilkesi & & 26 & 52 \\
\hline & & G.2 Bireyin kendini gerçekleştirme çabası & & 19 & 38 \\
\hline & $\begin{array}{l}\text { Bilgi } \\
\text { temellidir }\end{array}$ & $\begin{array}{l}\text { G.3Programda yer alan kazanımların bilgi basamağına yönelik olarak } \\
\text { hazırlanması }\end{array}$ & & 5 & 10 \\
\hline & & & Toplam & 50 & 100 \\
\hline \multirow{5}{*}{$\underset{\sum_{0}^{\infty}}{\stackrel{2}{Z}}$} & & Alt Temalar & & f & $\%$ \\
\hline & $\begin{array}{l}\text { Değer } \\
\text { temellidir }\end{array}$ & G.1 Bireyin kendini gerçekleştirme çabası & & 4 & 8 \\
\hline & \multirow{3}{*}{$\begin{array}{l}\text { Bilgi } \\
\text { temellidir }\end{array}$} & G.2 Kazanımların bilgi basamağına yönelik olması & & 26 & 52 \\
\hline & & G.3 Konunun somut olmas1 & & 20 & 40 \\
\hline & & & Toplam & 50 & 100 \\
\hline
\end{tabular}

Türkiye ve Avusturya'daki katıllımcı öğretmenlerin "Demokrasi eğitimi kapsammda ortaokul kademesinde işlenen konularn değerlere mi yoksa bilgiye dönüle olması ile ilgili neler düşünüyorsunų?? Niçin?” ş̧eklindeki soruya birbirinden farklı yanıtlar verdikleri Tablo 6'da görülmektedir. Türkiye'deki öğretmenlerin bu soruya birbirinden farklı yanıtlar verdiği görülse de katılımcıların büyük bir kısmının \%52 ile "Programda yer alan işlevsellik ve hayatilik ilkesi”alt temasında birleştikleri görülmektedir.. Avusturya'daki öğretmenlerin vermiş oldukları yanıtlarda birbirinden farklı olsada, ögretmenlerin büyük bir kısmının yeterli buldukları ve \% 52 ile "Kazanımların bilgi basamağına yönelik olması" alt temasında birleşmişlerdir.

Türkiye ve Avusturyadaki öğretmenlerin "Demokrasi eğitimi kapsammda ortaokul kademesinde işlenen konularn değerlere mi yoksa bilgiye dönül olması ile ilgili neler düs̆̈̈nüyorsunuz?? Niçin?"şeklindeki soruya ilişkin vermiş oldukları cevaplardan, bazılarının görüşleri aşağıda verilmiştir:

"Demokrasi eğitimine ilişkin ortaokul kademelerinde yer alan programlarda bana göre bireylere daba coke konu ile ilgili bilgiyi ezberletmekten ziyade, ögrenciye anlatılan konu ile ilgili becerileri ögrencinin hayatmm her safhasinda kullanarak bu becerileri icselleștirerek benimsemesidir.

'(G.1 T)

"Bireyin demokrasi eğitimine yönelik olarak edindiüg değerleri kullanarak kişilĭgine şekil vererek, bireyin bayat boyunca kendini gerçekleștirme süreci aşamasinda toplumda saygin bir birey olma çabasi içerisine girdiğinden programlarn değer temelli olduğunu düs̈̈̈ӥ̈оrum.'(G

'”(G.2 T) 
"Biz̧im ülkemizde demokrasi eğitimi ile ilgili bireye kazandımlmak istenen ögelerin bu eğitimin kapsamında olan değerler olduğunu düşünüyorum. Çünkü birey bu değgerler sayesinde topluma kendisini kabullendirme mücadelesinde galip gelmesine katki sağlayacaktır."(G.1 A)

"Ortaokul kademesinde yer alan programlarda, demokrasi eğitimi için haz̧rlanan kazanımlara bakuldı̆ğnda bu kazanmların bloomun bilisssel bedef taksonomisinin bilgi basamă̆ının ăgır bastı̆̆ görülmektedir. Ancak ben buna bak.arak fikerimi açılamayacă̆ım. Ben kişisel olarak herhangi bir konu ile ilgili olarak gerekli bilgi ögrenilmeden bu

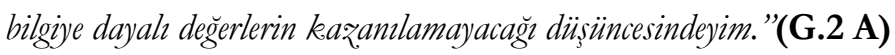

Türkiye'deki öğretmenlerin ortaokullardaki demokrasi eğitimi konularını değer temelli olarak değerlendiren görüşlerine göre; birey, konular ile ilgili becerileri hayatının her safhasında kullanılabileceği ve toplumda sayg1 görebileceği olarak değerlendirilirken, bilgi temelli olarak değerlendiren görüş; bütün programların amacının sadece bilgi vermek olarak belirtilmiştir. Avusturya'daki öğretmenlerin ise ortaokullardaki demokrasi eğitimi konularını değer temelli olarak değerlendiren öğretmen görüşüne göre; bireye kazandırılmak istenen öğeler, bireyin topluma kendisini kabullendirmesi için gerekli olan, eğitim kapsamındaki değerlerdir. Bilgi temelli olarak değerlendiren görüş; bir bilgi öğrenilmeden, bu bilgiye dayalı öğrenmenin gerçekleşmeyeceği olarak ifade edilmiştir.

\section{TARTIŞMA ve SONUÇ}

\subsection{Demokrasi eğitiminin tanımına ilişkin tartışma ve sonuç}

Avusturya ve Türkiye'deki katılımcıların demokrasi kavramının tanımına ilişkin algılarının farklı olduğu belirlenmiştir. Avusturyadaki katılımcılar demokrasi eğitimini \%36 “İfade özgürlügü”, \% 20 “İnsan haklarına sayg1", \% 16“Özgürlükçü anlayış”, \%12 "Bireyin kendi kendisini yönetme yetkisine sahip olması”, \%8 "Kurallara saygılı anlayış”, \%8 “Bireysel farklılıklara saygı” olarak görürken; Türkiye'deki katılımcıların ise \%24 “İfade özgürlüğü”, \% 16 “İnsan haklarına sayg1”, \% 16“Özgürlükçü anlayış”, \%12 “Toplumsal yaşama uyum”, \% 12 “Bireysel ifade özgürlüğü”, \%8 “Kurallara sayg1l1 anlayış”, \%8 “Eşitsel düzeyde eğitim”, \%4 “Yönetimde özgürlük” olarak gördükleri sonucuna ulaşılmıştır.

Her iki ülke katılımcılarının demokrasiyi farklı tanımlamalarına rağmen genel olarak "İfade özgürlüğü, İnsan haklarına saygı, Özgürlükçü anlayış ve Kurallara saygılı anlayışı” temalarında öğretmenlerin birleştikleri sonucuna ulaşılmıştır. Bireylerin demokratik bir yaşama sahip olmaları, onların öncelikli olarak düşüncelerini özgürce ifade etmelerine bağlıdır. Ayrıca birey demokratik bir toplumda eşit haklara sahip olduğundan, tüm bireyler gibi özgürdür (Aktaş, 2015; Ersöz \& Duruhan 2015; Hotaman, 2010; Okutan, 2010; Öztaşk1n \& İçen, 2015; Saracaloğlu, Uça, Baydilek \& Coşkun, 2013; Şimşek, 2011). Birey sahip olduğu eşit haklar ile farklı kişi ve düşüncelere de saygı duymalı ve farklılıkların olabileceğini kabul etmelidir. Aynı zamanda bireyler sahip olduğu demokratik haklar ile yönetimde seçme ve seçilme hakkına sahip olurlar (Linde \& Ekman, 2003; Öztaşkın \& İçen, 2015; Slev, 2014; Şimşek, 2011; Yeşil, 2004). Bununla birlikte kişi haklarının korunması için tüm toplum demokasi çeçevesinde belirlenmiş kurallara uymak zorundadır.

\subsection{Demokrasi eğitimine yönelik olarak ortaokul kademesi için hazırlanan programlarda yer verilen kazanımları yeterliliğine ilişkin tartışma ve sonuç}

Demokrasi eğitimine ilişkin ortaokullar için hazırlanan programda yer alan kazanımların yeterliliğine yönelik olarak elde edilen sonuçlara bakıldığında: Türkiye'deki öğretmenlerin ortaokullarda demokrasi eğitimine yönelik olrak hazırlanan kazanımları yetersiz buldukları belirlenmiştir. Çünkü demokrasi eğitimine yönelik kazanımların farklı düşünceleri kapsayacak şekilde oluşturulmayıp tek tip düşünceye göre oluşturulduklarını Türkiye 'deki katılımcılar belirtmişlerdir. Bireylerin demokrasi bilincine sahip olabilmesi için tek tip düşünceye sahip öğrenciler yetiştirmek yerine eleştirel düşünebilen, hoşgörüye açık,sorgulayıcı, haklarını bilen, problemlere karşı duyarlı, ürtken ve adil olan bireylerin yetiştirilmesi hedeflenmelidir (Şişman, Güleş \& Dönmez, 2010; Ŏguz, 2011). Ayrıca belirlenen bu kazanımların öğrenci ihtiyaçlarına ve öğrenci seviyesine göre hazırlanmadığı öğretmenler tarafından belirtilmiştir. tespit edilmiştir. Demokrasi eğitimine ilişkin kazanımlar hazırlanırken görelilik ilkesi ve işlevsellik ilkeleri dikkate alınarak hazırlanmalıdır (Er, Ünal \& Özmen, 2013). Bununla birlikte demokrasi içerikli kazanımlar erken yaştan itibaren öğrenciye kazandırıldığında, öğrenciler öğrendiklerini pekiştirerek kavrayacak ve yeni öğrenmeler için hazırbulunuşlukları yeterli olacaktır. 
Avusturya'daki öğretmenlerin ise ortaokullar için belirlenmiş demokrasi içerikli kazanımları yeterli buldukarı sonucuna ulaşılmıştır. Aynı zamandan katılımcılar bu kazanımların sosyal öğrenme kuramına uygun (Bayrakç1,2007) rol-model ve gözlemler yoluyla öğrenciye aktarılabildiğini belirtmişlerdir. Öğrenclerin demokrasiyi en iyi şekilde öğrenmeleri aynı zamanda okul ve sosyal çevrelerinde (Okul yöneticileri, öğretmenler, diğer yetişkin bireyler) bireylerin dmokratik tutum ve davranışlar sergilemesiyle mümkün olabilir (Ersöz\& Duruhan, 2015; Gürel, 2014; Oğuz, 2011)

4.3. Ortaokul kademesinde demokrasi eğitimine yönelik olarak verilen içeriği kapsam olarak yeterliliğine ilişkin tartı̧̧ma ve sonuç

Demokrasi eğitimine yönelik olarak hazırlanmış olan programlar içerik olarak Türkiye'deki katılımcılar ağırlıklı olarak "konuların uygulama alanı eksikliğı” olduğundan yetersiz olduğu; Avustruya'daki öğretmenlerin ise içeriğin "Farklı öğrenme alanlarının sağladığı katkı" ve "Birbirinden farklı birden çok konunun yer almasından" ötürü yeterli buldukları sonucuna ulaşılmışır. Demokrasi eğitimine yönelik olarak hazırlanan içeriğin uygulanabilir olması, öğrenciye aktarım açısından önemlidir (Yeşil, 2004). İçeriğin farklı konulardan oluşması öğrencinin demokrasiyi tam olarak kavramasının sağlayacaktır. Ayrıca içeriğin uygulamaya dönüşmesi öğrencide istenilen davranışların kalıcılığını sağlayacaktır.

\subsection{Ortaokul kademesinde demokrasi eğitimine yönelik olarak verilen içeriğin aktarımına ilişkin tartışma ve sonuç}

Avusturya ve Türkiye'deki öğretmenlerin Demokrasi eğitimine yönelik içeriğin öğrenciye aktarımında hem ülkemizde hem de Avusturya'da aşamalılık ilkelerine uyulması gerekliliğine sonucuna ulaşılmıstır. Katılımcılar bilgi aktarımında bilinenden bilinmeyene, kolaydan zora, basitten karmaşığa, yakından uzağa ilkelerinin dikkate alınması gerektiğini belirtmişlerdir. Türkiye'deki öğretmenler demokrasi eğitimi içeriğinin aktarımında öğretim ilkelerinin benimsemesi gerektiğini ifade etmiş ve katılımcılar ağırlıklı olarak “Öğrenmede birikimli olarak ilerleme” temasında birleşmişlerdir. Avusturya’daki katılımcıların ise ağırlıklı olarak ögrencilerin aktif katılımının sağlanması için aşamalılık ilkeleri dikkate alınarak öğrenciye bilginin aktarılması gerektiğini belirtmişlerdir. Öğrencilerin demokrasi eğitimi içerikli konuları öğrenip kavramaları için aşamalılık ilkesini dikkate alınmalıdır. Öğrencilere öncelikli olarak basit olan konular öğretilmeli, soyut kavramlar somutlaştırılarak (Demir, 2016; Tutkun \& Okan, 2012) anlamlı öğrenme sağlanmalıdır. Öğrencilerin daha önce öğrenmiş olduğu bilgiler dikkate alınarak bu bilgiler pekiştirilmeli ve yeni bilgiler öğrenciye aşamalı olarak aktarılmalıdır. Böylece öğrencide kalıcı öğrenme gerçekleşecektir.(Demir, 2016; Tutkun \& Okan, 2012 Yakar, 2016).

\subsection{Demokrasi eğitimi kapsamında ortaokul kademesinde işlenen konuların değerlere mi yoksa bilgiye dönük olmasına ilişkin tartışma ve sonuç.}

Demokrasi eğitimi kapsamında ortaokul sosyal bilgiler dersinde işlenen konuların değerlere mi yoksa bilgiye dönük olması gerktiğine ilişkin elde edilen sonuçlara bakıldığında Türkiye'de demokrasi eğitiminin daha çok değerlere, Avusturya'da ise bilgiye yönelik olduğu sonucuna ulaşılmıştır. Bu doğrultuda öğretmenler genel olarak işlenilen konuların değerlere yönük olarak "Programda yer alan işlevsellik ve hayatilik ilkesi” temasında birleştikleri görülmektedir. Avusturya’daki öğretmenler ise, demokrasi içerikli konuları bilgi temelli değerlendirmiş ve genel olarak "kazanımların bilgi basamağına yönelik olması" teması altına katılımcı görüşlerinin birleştiği görülmektedir. Ders içinde verilen demokrasi içerikli bilgiler öncelikli olarak bilgi düzeyinde öğrenciler tarafından tam olarak kavranmalıdır. Öğrencilerin demokratik konular ve kavramlar hakkında yeterli bilgiye sahip olmamaları, onların demokrasi bilincini içselleştirmemelerini ve günlük yaşamda uygulamamalarına yol açabilir (Doğanay, 2005; Ulusoy, 2010).

\section{Öneriler}

Araştırmada elde edilen sonuçlar sonucunda şu öneriler de bulunulabilir:

$\checkmark$ Avusturya ve Türkiye'de demokrasi eğitimine yönelik hazırlanan kazanımlar ve bunun paralelinde hazırlanan içerik öğrencinin gelişim düzeyi ve ihtiyaçları göz önüne alınarak hazırlanabilir. 
$\checkmark$ Avusturya ve Türkiye'de demokrasi eğitimine yönelik bilgi ve değerlerin aktarımında öğrencinin uygulamaya dayalı becerilerini geliştiren strateji, yöntem ve teknikler kullanılabilir.

$\checkmark$ Avusturya ve Türkiye'de demokrasi eğitimine yönelik olarak öğrenciye kazandırılması gereken kazanımların aktarımında içeriksel boyutta araç-gereç ve materyallerden yararlanılarak somutlaştırma arttırılabilir.

$\checkmark$ Avusturya ve Türkiye'deki ortaokullarda görev yapan tarih ve sosyal bilgiler öğretmenlerine demokrasi eğitimi çerçevesinde sempozyumlar, hizmet içi eğitim kursları, konferanslar, workshoplar (çalıştaylar) düzenlenerek; öğretmenlerin demokrasi eğitimine ilişkin algisal tutumları geliştirilebilir.

$\checkmark$ Avusturya ve Türkiye'de demokrasi eğitimine yönelik olarak hazırlanan programların hazırlanmasında demokrasi eğitimi alanında uzman olan bireylerin görüşlerinden yararlanılarak demokrasi eğitimi açısından nitelikli bir program hazırlanılabilir.

\section{KAYNAKÇA}

Aktaş, M. (2015). Demokrasi Kavramına Eleştirel Bir Bakış. Muş Alparslan Ünïversiitesi Sosyal Bilimler Dergisi, 3 (1), 87-105.

Başgil, A. F. (2006). Demokrasi Yolunda. (2. baskı). İstanbul: Yağmur Yayınlar.

Bayrakc1, M. (2007). Sosyal Öğrenme Kuramı ve Eğitimde Uygulanması. SAÜ Ë̆itim Fakültesi Dergisi, 198-210 Beetham, D.,ve Boyle, K. (1998). Demokrasinin Temelleri. (Çev. V. Bıçak). Ankara: Liberte Yayınları.

Çam, E. (2002). Siyaset Bilimine Giriş.(8. bask1). İstanbul: Der Yayınları.

Dağı, İ. D., ve Polat, N. (1999). Demokrasi ve İnsan Haklarn El Kitabı. Ankara: Türk Demokrasi Vakfi.

Dahl, R.A. (2001). Demokrasi Üstüne.(Çev. B. Kadıŏlu). Ankara: Phoenix Yayınevi.

Demir, S. B. (2016). Sosyal Bilgiler eğitimi ve V atandaşlık bilgisi. S. B. Demir. (Ed.). Vatandaşlık bilgisi içinde (ss. 2-14). Ankara: An1.

Dewey, J. (2010). Günümüzde Eğitim. J. Ratner (Editör), B. Ata ve T. Öztürk (Çev. Editörleri). Günümüz Dünyasında Demokrasi ve Eğitim. (Çev. H. Çalışkan). Ankara: Pegem Yayıncilık.

Doğanay, A. (2005). Sosyal bilgiler ögretimi. C. Öztürk \& D. Dilek (Edt.). Hayat Bilgisi ve Sosyal Bilgiler ögretimi (5. bask1) içinde (ss.18-54). Ankara: Pegem Akademi.

Duman, T., Karakaya, N.,ve Yavuz, N. (2001). Vatandaşhlk Bilgisi. Ankara: Gündüz Eğitim ve Yayıncılık.

Eley, G. (2008). Demokrasiyi Kurmak Avrupa Solunun Taribi 1850-2000. (Çev. A. Y. Güney). İstanbul: Doruk Yayıncilik.

Er, H., Ünal, F. \& Özmen, C. (2013). 8.Sınıf Vatandaşlık ve Demokrasi Eğitimi Dersinin 4. Sınıfa Alınmasına İlişkin Görüşler Üzerine Bir Araştırma. International Journal of Social Science, 6 (8), 179-196.

Ersöz, Y. \& Duruhan, K. (2015). Okul ortamında demokrasi yaşantıları. İnönü Üniversitesi Eğitim Bilimleri Enstitüsü Dergisi, 2 (3), 13-26

Gözübüyük, Ş. (2007). Anayasa Hukuku Anayasa Metni ve 11. Protokole Göre Hažrlanmıs Avrupa Insan Haklar Sözleşmesi. (15. baskı). Ankara: Turhan Kitabevi Yayınları.

Gürel, R. (2014). Sosyal Pekiştireçlerin ve Model Davranışlarının, Çocukların Ahlaki Yargılarının Şekillenmesindeki Etkisi (Bandura Örneği). Değerler Eğitimi Dergisi, 12 (28), 101-119

Hancock, B. (1998). Trent focus for research and development in primary health care: an introduction to qualitative research. Trent Focus Group

Hobbes, T. (2007). Elementa Philosophica De Cive Yurttaşlke Felsefesinin Temelleri. (Çev. D. Zarakolu). İstanbul: Belge Yayınları.

Hotaman, D. (2010). Demokratik Eğitim: Demokratik Bir Eğitim Programı. Kuramsal Eğitimbilim, 3 (1), 29-42, 2010

Kışlalı, A.T. (1987). Sijaset Bilimi. Ankara: Ankara Üniversitesi Basın-Yayın Yüksekokulu Yayınları. 
Kozaner, Ç. (2012). Sosyal Bilgiler Ögrretmen Adaylarmm İlköğretim İkinci Kademe Sosyal Bilgiler Derslerindeki Demokrasi Konularna Yönelik Görüsleri (Gaz̨i Üniversitesi Örneği). Yayınlanmamış Yüksek Lisans Tezi, Gazi Üniversitesi Eğitim Bilimleri Enstitüsü, Ankara

Leser, C. (2011). Politische Bildung in und Durch Schule.Wiesbaden: Vs-Verlag.

Linde, J., \& Ekman, J. (2003). Satisfaction with democracy: A note on a frequently used indicator in comparative politics. European Journal of Political Research, 42(3), 391-408. Doi: 10.1111/14756765.00089

Oğuz, A. (2011). Öğretmen Adaylarının Demokratik Değerler ile Öğretme ve Öğrenme Anlayışları. Değerler Eğitimi Dergisi, 9 (22). 139-160

Okutan, M. (2010). Türk Eğitim Sistemi'nde demokrasi eğitimi. Uluslararası İnsan Bilimleri Dergisi, 7 (1), $938-946$

Öztaşkın, Ö. B., \& İçen, M. (2015). Ortaokul öğrencilerinin hoşgörü eğilimleri ile demokrasi algıları arasındaki ilişskinin incelenmesi. Karadeniz. Sosyal Bilimler Dergisi, 7(02).

Saracaloğlu, A. S., Uça, S., Başara Baydilek, N. \& Coşkun, N. (2013). Öğretmen adaylarının demokratik tutumları ile değer alg1larının incelenmesi. Adnan Menderes Üniversitesi Eŭitim Fakültesi Eğitim Bilimleri Dergisi, 4(1), 45-59.

Saray, M. (1999). Türk Devletlerinde Meclis (Parlamento), Demokratik Düsünce ve Atatürk. Ankara: Atatürk Araştırma Merkezi Yayını.

Slev, A. M. (2014). Perceptions of democracy and democratic principles among Romanian law students. Land Forces Academy Review, 19(1), 38-44.

Şimşek, N. (2011). İlköğretim sosyal bilgiler dersinde öğrencilerin demokratik kazanımlarının çeşitli değişkenler açısından incelenmesi. Milli Ë̆gitim, 190, 188-202

Şişman, M. (2006). Eğitimde demokrasi ve sosyal adalet: Türkiye eğitim sisteminindeğişmeyen miti. Türk Eğitim Sisteminde Yeni Paradigma Arayışları Bildiriler Kitab1, 4-5 Kasım,Ankara. Eğitim Bir-Sen Yayınları, 291-305.

Şişman, M., Güleş, H. \& Dönmez, A. (2010). Demokratik Bir Okul Kültürü İçin Yeterlilikler Çerçevesi. Uşak Üniversitesi Sosyal Bilimler Dergisi, 3 (1), 167-182

Tanilli, S. (1996). Devlet ve Demokrasi Anayasa Hukukuna Giriş. (8.Baskı). İstanbul: Çağdaş Yayınları.

Tutkun, Ö. F., \& Okay, S. (2012). Bloom’un Yenilenmiş Taksonomisi Üzerine Genel Bir Bakış. Sakarya University Journal of Education, 1(3), 14-22.

Ulusoy, K. (2010). İlköğretim Sosyal Bilgiler Öğretmen Adaylarının Laiklik Kavramının Öğretimi İle İlgili Görüşleri.Milli Eğitim Dergisi, 40 (185), 300-313

Uygun, O. (2003). Demokrasinin Taribsel Felsefi ve Ablaki Boyutlar. İstanbul: İnk1lâp Kitabevi.

Üste, B. (2011). Siyaset Bilimi. İstanbul: Beta yayınlar1.

Weiss, M. (2010). Die Direkte Demokratie. Austria: Verlagholzhausengmbh.

Yakar, A. (2016). Geleceğin Eğitimi Üzerine Program ve Tasarım Modeli Önerileri: "Yaşamsal Eğitim Programları" ve "Yaşamsal Öğretim Tasarımları. MSKU Ë̆gitim Fakültesi Dergisi, 3 (2), 1-15

Yeşil, R. (2003). Demokratik Eğitim Ortamının İnsan Hakları Temeli. G.Ü. Kerşehir Eğitim Fakültesi Dergisi, $4(2), 45-54$.

Yeşil, R. (2004). İnsan Hakları Ve Demokrasi Eğitiminde Yöntem. G.Ü. Krrşsehir Eğitim Fakültesi Dergisi, 5 (1), $35-41$

Yıldırım, A., ve Şimşek, H. (2008). Sosyal Bilimlerde Nitel Araştırma Yöntemleri. Ankara: Seçkin Yayınları.

Yıldırım, İ. (2004). Demokrasi Sivil Toplum Kuruluslar ve Yönetişim. Ankara: Seçkin Yayıncılık.

Yılman, M. (2006). Demokrasimiz̨in Kültürel Temelleri. (10.Baskı). Ankara: Nobel Yayınları. 